\title{
Taksonomi Intervensi Seni Kreatif untuk Kesehatan Mental
}

\author{
Anrilia Ema M.N ${ }^{1}$, Wanda Listiani ${ }^{2}$ \\ ${ }^{1}$ Universitas 17 Agustus 1945 Surabaya, Jalan Semolowaru 45 Surabaya \\ 2,Institut Seni Budaya Indonesia Bandung, Jalan Buahbatu No. 212 Bandung 40265 \\ Tlp.0818172897,E-mail: anrilia.ningdyah@untag-sby.ac.id
}

\begin{abstract}
Creative arts interventions develop across disciplines of art and psychology. The aim of this research is to map the development of art psychology research, in particular the taxonomy of creative arts interventions for mental health. Art is used as an intervention in the treatment for patients or non-patients with mental health disorders. The Covid-19 outbreak causes stress and significantly affects individual's mental health. This research utilized quantitative method with bibliometric analysis of data obtained from the Scopus database. Seven keywords were used for data search: "psychology", "art", "art therapy", "psychotherapy", "psychosis", "psychosis art" and "pandemic". Results were exported in CSV format. The data was analyzed based on abstract and year of publication. Exported data was then processed and analyzed using VOSViewer to find out the bibliometric map of the development of research on art psychology indexed in the Scopus database since 1896 to 2021. The results illustrate taxonomy of creative arts interventions for mental health and topics that often arise in the realm of art psychology.
\end{abstract}

Keywords: art psychology, art interventions, mental health, taxonomy.

\begin{abstract}
ABSTRAK
Intervensi seni kreatif berkembang dalam lintas disiplin ilmu seni dan psikologi. Tujuan penelitian ini adalah untuk memetakan perkembangan penelitian psikologi seni khususnya taksonomi intervensi seni kreatif untuk kesehatan mental. Seni digunakan sebagai intervensi dalam upaya penyembuhan pasien atau non pasien yang mengalami gangguan kesehatan mental. Wabah Covid-19 menimbulkan stress dan secara signifikan mempengaruhi kesehatan mental individu. Metode penelitian yang digunakan adalah metode kuantitatif dengan analisis bibliometrik. Data diperoleh dari basis data scopus. Tujuh kata kunci untuk penelusuran data yaitu "psychology", "art", "art therapy", "psychotherapy", "psychosis", "psychosis art" dan "pandemic". Hasil penelusuran di export dalam bentuk format CSV. Data dianalisis berdasarkan abstrak dan tahun terbit. Data hasil export kemudian diolah menggunakan VOSViewer untuk mengetahui peta bibliometrik perkembangan penelitian psikologi seni yang terindeks di basis data scopus sejak tahun 1896 s.d 2021. Hasil penelitian menggambarkan taksonomi intervensi seni kreatif untuk kesehatan mental dan topik yang sering muncul dalam ranah ilmu psikologi seni.
\end{abstract}

Kata kunci: psikologi seni, intervensi seni, kesehatan mental, taksonomi

\section{PENDAHULUAN}

Gejala kesehatan mental dan tekanan sosial seperti ketidakpastian akibat Covid-19 mempengaruhi sebagian besar kondisi kesehatan masyarakat. Seni visual dapat mengurangi tingkat depresi (depression) dan kecemasan (anxiety), meningkatkan selfrespect, self-worth dan self-esteem, mendorong 
terlibat dalam kegiatan sosial yang lebih luas dan negosiasi kembali identitas melalui karya seni berbasis praktik. Seni visual sebagai ruang aman yang nyaman untuk intervensi. Konsep self-worth, self-esteem, percaya diri, depresi, kecemasan dan ukuran bukti laporan diri dalam kesejahteraan subjektif. Gambar mandala dapat mengurangi gejala trauma untuk suffering dari post-traumatic stress disorder (PTSD) dan keterlibatan dalam kegiatan budaya yang mengubah self-reported kesehatan dan mengurangi gejala tentang exhaustion untuk perempuan dengan burnout (Tomlinson et.all, 2018, hlm. 3-6).

Kesehatan mental menurut WHO (Sau, 2018, hlm. 1) adalah keadaan well-being di mana setiap individu menyadari potensi dirinya, dapat mengatasi tekanan kehidupan yang normal, dapat bekerja secara produktif dan bermanfaat, dan mampu memberikan kontribusi pada dirinya dan komunitas/ masyarakat. Kondisi mental merupakan dimensi yang sangat penting untuk kesehatan dan well-being setiap individu. Well-being (Sirgy, 2012, hlm. vii) menentukan kualitas hidup. Kualitas hidup terdiri dari tiga aspek utama yaitu well-being hedonis, kepuasan hidup dan eudaimonia. Istilah well-being dapat dipertukarkan dengan istilah well-being emosional, kebahagiaan, komponen afektif well-being subyektif, efek positif dan negatif, dan lain-lain. Kepuasaan hidup merujuk pada konsep kognitif well-being subjektif. Sedangkan eudaimonia dipahami sebagai wellbeing psikologis, aktualisasi diri, realisasi diri, pertumbuhan individu, pengembangan diri, kesehatan mental, berkembang dan sebagainya. Dari penelitian yang dilakukan oleh L.K. Jenkins dkk (2021, hlm. 121-126) terhadap 65 responden yang di diagnosa menderita demensia dan pengaruhnya pada proyek artistik. Penelitian ini menjelaskan terdapat hubungan antara praktik seni dan kesehatan publik termasuk well-being psikologis. Terdapat 5 (lima) indikator well-being yaitu emosi positif, keterlibatan, hubungan positif, makna dan pencapaian atau prestasi.

Depresi dan kecemasan merupakan 2 (dua) hal yang penting dalam spektrum gangguan kesehatan mental. Disabilitas akibat masalah kesehatan mental meningkat di dunia. Kecemasan dan depresi merupakan gangguan kesehatan mental utama. Dampak kecemasan dan gangguan depresi pada kesehatan dan well-being sangat multidimensional. Satu sisi, beberapa gejala somatik seperti asam lambung, gastritis, palpitasi, tremor, insomnia atau hypersomnia, penurunan atau kenaikan berat badan, manifestasi psikososial yang berbeda seperti penarikan sosial, depresi, keinginan bunuh diri atau usaha bunuh diri, penurunan produktivitas dalam tempat kerja, kurang konsentrasi dan lain-lain. Kecemasan dan depresi menyebabkan gaya hidup penyakit lainnya seperti hipertensi, penyakit jantung, diabetes dan cedera disengaja atau tidak disengaja.

Penyebab kecemasan dan depresi bersifat multifaktor (Sau, 2018, hlm. 2) yaitu biologi, ekonomi, sosial, lingkungan dan budaya. Tidak ada mekanisme dan alat untuk mengetahui individu yang menderita kecemasan dan depresi dari populasi umum yang tampaknya sehat. Perlunya pengembangan sistem untuk screening 
Bagan 1. Hierarki Taksonomi PTSD (Sumber: Kagan, 2013, hlm. 25)

PTSD

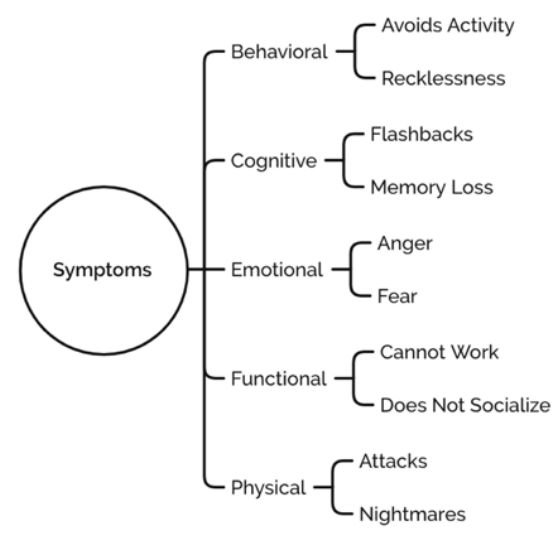

populasi berisiko menderita kecemasan dan atau depresi. Selain keterbatasan alat screening berbasis kuesioner yang ada, dikembangkan sistem baru deteksi kecemasan dan depresi didasarkan pada kriteria objektif yang jelas berdasarkan taksonomi dan pemetaan ilmu pengetahuan.

Taksonomi (Anderson et.al, 2001, hlm. xxi-xxii) merujuk pada sistem klasifikasi. Taksonomi berdampak pada kualitas pendidikan yang berpengaruh pada cara berpikir dan bertindak seorang pendidik. Taksonomi dibagi dalam 2 dimensi yaitu pengetahuan dan proses kognitif. Pengetahuan umum dalam pendekatan psikologi kognitif (Anderson et.al, 2001, hlm. 27) dibagi menjadi 4 jenis yaitu faktual, konseptual, prosedural dan metakognitif. Hierarki taksonomi PTSD berdasarkan gejalanya dibagi menjadi perilaku, kognitif, emosi, fungsional dan fisik. Hierarki taksonomi PTSD dapat dilihat pada bagan 1.

Pemetaan ilmu pengetahuan merupakan metode visualisasi bidang ilmu dalam bentuk peta bibliometrik. Peta bibliometrik. yang memunculkan topik dari ilmu pengetahuan yang berasal dari data bibliografis, kata kunci, sitasi, pengarang, judul dan lain sebagainya. Peta ilmu pengetahuan atau bibliometrik dapat memperlihatkan pertumbuhan suatu bidang ilmu tertentu. Hal ini dapat membantu peneliti untuk menentukan area penelitiannya. Kata kunci yang ditulis oleh penulis dapat dianalisis dan dihitung. Semakin banyaknya kata kunci pada sekelompok dokumen menunjukkan semakin kuat hubungan antara dokumen tersebut. Analisis co-word digunakan untuk menghitung banyaknya kata kunci dari suatu dokumen penelitian yang muncul secara bersamaan pada dokumen yang diteliti.

Peta berdasarkan analisis co-word dari kata kunci adalah peta yang didasarkan atas co-occurrence istilah-istilah penting atau unik yang terdapat dalam artikel dan bisa dilihat dengan melihat judul atau abstraknya saja. Istilah yang didapat dari analisis subjek mewakili suatu konsep. Analisis makna teks dan co-word menunjukkan pola dan tren dalam psikologi seni.

\section{METODE}

Penelitian ini bertujuan untuk menggambarkan tren tema dan struktur pengetahuan psikologi seni dengan menggunakan analisis co-word (Zhao, 2018, hlm. 1). Penelusuran dilakukan pada basisdata scopus di laman www.scopus. com menggunakan 7 (tujuh) kata kunci yaitu "psychology", "art", "art therapy", "psychotherapy", "psychosis", "psychosis art" dan "pandemic". Dari hasil penelusuran ditemukan sebanyak 3662 artikel tentang psikologi seni dari tahun 1896-2021. Data penelitian di export dalam format CSV (Comma Separated Values) 
untuk membuat taksonomi intervensi seni kreatif. Data kemudian diolah dan dianalisis dengan VOSViewer untuk membuat peta bibliometrik psikologi seni.

Bibliometrik digunakan dalam analisis kuantitatif dan menelusuri topik terhangat dalam literatur. Bibliometrik membantu peneliti untuk memonitor perkembangan dan pola spefisik ranah keilmuan. Metode seperti analisis co-citation dan analisis co-word yang digunakan untuk mencari topik hangat penelitian. Analisis co-word (Zhao, 2018, hlm. 1) adalah metode analisis isi yang didasarkan pada prinsip yang dipilih pada literatur yang merepresentasikan seperangkat kata. Hubungan antar kata didefinisikan dengan frekuensi co-existence pada artikel yang sama. Bibliometrik (Chandrashekara, 2010, hlm. 20) menggunakan analisis kuantitatif dan statistik untuk mendeskripsikan pola publikasi dalam ranah literatur. Bibliometrik untuk menentukan pengaruh seorang penulis tunggal atau menggambarkan hubungan dua atau lebih penulis atau karya. Sitasi (Chandrashekara, 2010, hlm. 21) digunakan peneliti untuk mengungkapkan hubungan antar pustaka.

Bibliometrik mengungkapkan pola kolaborasi internasional dan dalam profil institusi digunakan untuk menggambarkan tingkat klasifikasi subyek hirarkis untuk mengembangkan indikator sitasi subyek yang dinormalkan. Bibliometrik (Chandrashekara, 2010, hlm. 22) adalah studi berkaitan dengan analisis dan penggambaran literatur dengan mengadopsi metode matematika atau statistik untuk mengajukan proposisi teori. Analisis bibliometrik yang menghasilkan variasi dalam pola publikasi. Bibliometrik membantu menelusuri tren penelitian dalam disiplin ilmu bersangkutan. Analisis co-word (Yue, 2011, hlm. 129) adalah teknik bibliometrik yang digunakan untuk membuat peta ilmu pengetahuan dan hubungannya dengan topik. Berdasarkan frekuensi co-occurrence tentang kata atau frase, analisis co-word digunakan untuk menemukan keterkaitan antara subyek dalam ranah penelitian dan pengembangannya dalam ilmu pengetahuan.

Analisis co-word (Delectroix, 2004, hlm. 80) digunakan untuk mengukur kekuatan asosiasi antara istilah dalam dokumen untuk mengungkapkan dan memvisualisasikan evolusi bidang ilmu psikologi seni melalui pengelompokkan dan diagram. Analisis co-word (Delectroix, 2004, hlm. 81) mengungkapkan pola dan tren dalam wacana psikologi seni dengan mengukur kekuatan asosiasi istilah yang merepresentasikan relevansi publikasi dan pola. Asosiasi merepresentasikan peta struktur konseptual untuk bidang ilmiah tertentu. Algoritma coword diproses dalam 2 (dua) tahapan untuk menghasilkan koneksi pasangan istilah.

Adapun tahapan penelitian yang dilakukan adalah pertama, membangun jaringan yang dapat mengidentifikasi area fokus yang kuat. Kedua, mengidentifikasi istilah yang terkait di lebih dari satu jaringan sehingga menunjukan keterkaitan masalah. Ketiga, analisis word cloud. Word cloud (McNaught, 2016, hlm. 630) adalah visualisasi teks untuk melihat frekuensi kata yang digunakan secara efektif dalam sebuah representasi. Kata-kata yang ditunjukkan adalah kata penting yang paling sering 
muncul. Word cloud mengungkapkan frekuensi kata berbeda yang muncul dalam teks. Komposisi kata memungkinkan untuk melihat gambaran umum tentang topik utama dan tema utama dalam sebuah teks, dan dapat menggambarkan sudut pandang utama yang dipegang oleh penulis teks. Word cloud (McNaught, 2016, hlm. 641) dapat dengan cepat memvisualisasikan beberapa pola umum dalam teks. Visualisasi memungkinkan peneliti untuk memahami tema umum dalam teks, dan perbedaan utama antar teks.

\section{HASIL DAN PEMBAHASAN}

Dari hasil analisis bibliometrik dijelaskan bahwa ranah penelitian psikologi seni yaitu kreativitas, estetika dan proses kreatif. Hal ini berbeda dengan hasil penelitian Schoch dan Ostermann (2021, hlm. 373) bahwa ranah penelitian psikologi seni adalah kreativitas dan relasi psikologi pada seni. Kreativitas dalam penelitian psikologi (Weiss, 2020, hlm. 1) diukur dalam hubungannya dengan disposisi kepribadian lainnya. Kemiripan kreativitas dengan orisinalitas dan kreativitas sebagai proses rekombinasi elemen mental dalam seni terapan. Hal ini juga diungkapkan dalam penelitian yang dilakukan oleh Henry Shevlin (2021, hlm. 16) kreativitas dalam inspirasi artistik dan penemuan yang membedakan bentuk kehidupan manusia dan konsekuensinya pada yang lain. Konsep ini berbeda dengan pengertian kreativitas sebagai sebuah ranah (Piliang, 2014, hlm. 286) yang berinteraksi dengan yang lain. Kreativitas psikologis atau kecerdasan kreatif merupakan pemikiran dan perilaku kreatif seperti tindakan imajinasi, penalaran dan pemecahan masalah secara cerdik, rasa ingin tahu, bermain dan eksplorasi. Kreativitas dalam permainan digital dikonsepsikan sebagai cara berpikir, konstruksi permainan dan permainan sebagai bentuk seni (Hall, 2019, hlm. 1). Kreativitas dapat terjadi pada kelompok yang melakukan kolaborasi untuk menciptakan produk bersama dalam situasi yang tidak terbatas dan tidak terduga. Proses kreativitas kolaboratif terjadi pada individu yang melampaui batas pengetahuan mereka sendiri melalui proses penemuan pikiran dan perasaan baru, perspektif, improvisasi dan tingkat masalah dalam suatu kegiatan.

Psikologi seni dan estetika (Silvia et.al, 2021, hlm. 1) memiliki minat pada bagaimana fitur seperti simetri, kelengkungan, warna mempengaruhi pengalaman estetika seseorang. Seni (Larrain, 2020, hlm. 800) dipahami dalam teori Psikologi Seni Vygotsky sebagai teknik sosial untuk kembali membangun kehidupan dan mengubah tubuh. Sedangkan emosi manusia adalah proses dialogis yang diciptakan secara kultural dan semiotik. Kemudian hierarki taksonomi pada bidang ilmu psikologi seni dibagi menjadi 2 (dua) yaitu intervensi seni dan assessment/ screening seperti yang digambarkan pada bagan 2 .

Hasil penelitian yang dilakukan oleh Abdullah Khalili dan Hamid Bouchachia (2021, hlm. 1) tentang assessmen estetika pada 56 fitur visual dari sebuah gambar untuk mengklasifikasikan pada gambar "indah" atau "buruk rupa". Fitur yang digunakan antara lain rata-rata intensitas pixel, frekuensi warna relative, saturasi, aspek 
Bagan 2. Hierarki Taksonomi Psikologi Seni

(Sumber : Hasil Penelitian, 2021)

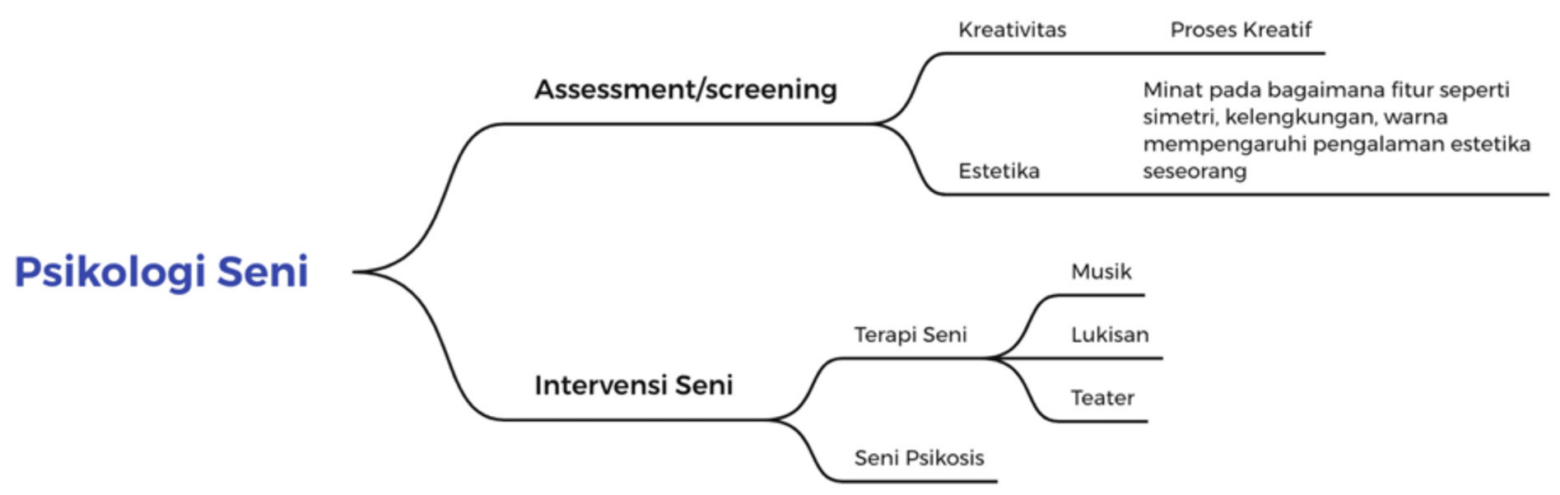

rasio, tekstur, kedalaman bidang, warna, blur dan sebagainya. Hasil penelitian ini menunjukkan bahwa gambar yang menarik secara estetika memberikan jumlah informasi lebih tinggi pada beberapa tingkatan. Hasil penelitian lain tentang preferensi estetika manusia dan evolusi kreatif dan sistem generatif yang dilakukan oleh Joh McCormack dan Andy Lomas (2020, hlm. 1). Terdapat hubungan antara ukuran kompleksitas gambar dan evaluasi estetika manusia. Penggunaan metode reduksi dimensi untuk memvisualisasikan antara ruang fenotipe dan genotipe dalam mengeksplorasi wilayah baru baru sistem generatif.

Penelitian seni sebagai intervensi trauma pasca stres dilakukan oleh (Fernandez-Cao, 2020, hlm. 1). Gambar artistik digunakan untuk terapi di pusat budaya dan ruang klinis dengan instrumen PROJECTA. Hasil penelitian ini menjelaskan hubungan antara 220 gambar artistik dengan keadaan emosi, perasaan atau pikiran terkait dengan pengalaman traumatis responden. Terdapat 92 karya seni yang dikaitkan dengan emosi primer, sekunder dan tersier seperti cinta, gembira, menang, kejutan, keseimbangan, rasa humor dan marah. Seni sebagai terapi juga dijelaskan
Tabel 1. Analisis Subyek Artikel (Sumber : Hasil Penelitian, 2021)

\begin{tabular}{clcc}
\hline No. & Kata Kunci & Jumlah & Persentase \\
\hline 1. & $\begin{array}{l}\text { Psikologi } \\
\text { Seni dan } \\
\text { Pandemi }\end{array}$ & 61 & $1,6 \%$ \\
& & \\
\hline 2. & $\begin{array}{l}\text { Psikologi } \\
\text { Seni }\end{array}$ & 1952 & $53 \%$ \\
\hline 3. & Terapi Seni & 13 & $0,4 \%$ \\
\hline 4. & $\begin{array}{l}\text { Psikoterapi } \\
\text { dan Seni }\end{array}$ & 811 & $22 \%$ \\
\hline 5. & Seni Psikosis & 825 & $23 \%$ \\
\hline & & $\mathbf{3 6 6 2}$ & $\mathbf{1 0 0 \%}$ \\
\hline
\end{tabular}

dalam penelitian James Carney (2019, hlm. 1). Terapi seni melalui gambar, narasi dan film sebagai jenis representasi budaya. Terapi seni (Christiani, 2021, hlm. 109) adalah terapi yang menggunakan media seni sebagai media. Representasi budaya ini digunakan untuk pengobatan gangguan depresi dan kecemasan. Selain analisis bibliometrik dan hierarki taksonomi pada bidang ilmu psikologi seni . Dari hasil analisis subyek menjelaskan bidang atau topik penelitian dari sebanyak 3662 artikel dapat dilihat pada tabel 1 .

Dari jumlah subyek artikel yang ditemukan pada basis data scopus digambarkan grafik 1 . 
Grafik 1. Jumlah Subyek Artikel

(Sumber : Hasil Penelitian, 2021)

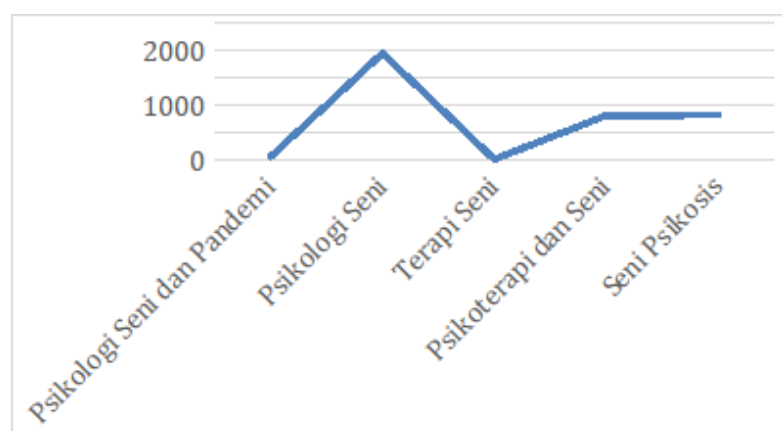

Dari grafik diatas menunjukkan perkembangan topik yang paling banyak diteliti dalam basis data scopus adalah psikologi seni sejumlah 1952 artikel. Jika topik psikologi seni dikaitkan dengan pandemi ditemukan sebanyak 61 artikel. Dari hasil analisis subyek artikel tersebut kemudian dibuat peta co-word. Peta co-word dari kata kunci menjadi dasar pemetaan co-occurrence terhadap istilah penting atau unik dalam artikel tertentu. Hasil visualisasi network peta co-word sebagai berikut:

\section{A. Kata Kunci Psikologi Seni dan Pandemi}

Dari hasil penelusuran di basis data scopus dengan kata kunci art psychology dan pandemic. diperoleh sebanyak 61 artikel. Hasil pengelompokan kata kunci dari analisis menggunakan perangkat lunak VOSviewer sebagai berikut :

1. Kelompok warna merah terdapat $\mathbf{1 0}$ topik yaitu mental health, epidemic, epidemiology, physiology, art therapy, prevention, virus transmission, depression, epidemic, public health.

2. Kelompok warna hijau terdapat $\mathbf{1 4}$ topik. Topik yang paling banyak adalah human, psychology, covid-19. Kemudian dilanjutkan dengan topik

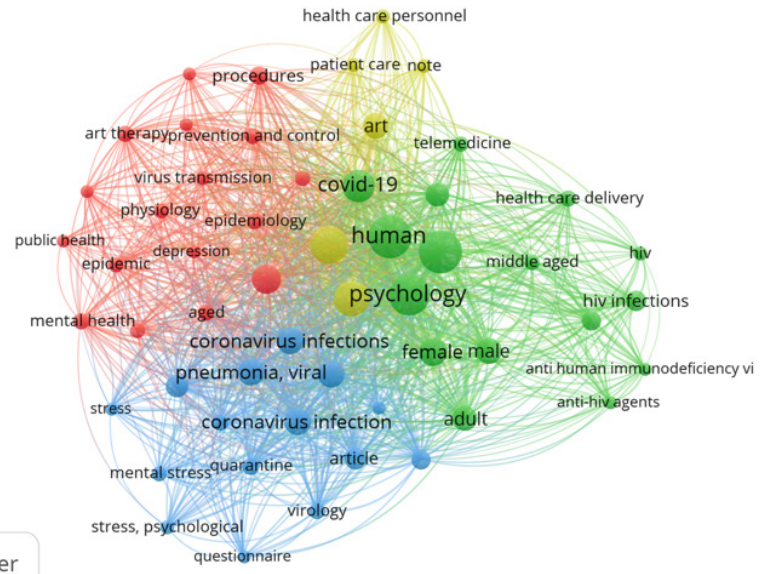

Gambar 1. Analisis Bibliometrik Psikologi Seni dan Pandemi

(Sumber : Hasil Penelitian, 2021)

female, male, adult, hiv infections, middle aged, telemedicine, health care delivery, anti human immunodeficiency vi, anti-hiv agents, hiv.

3. Kelompok warna biru terdapat 9 topik. Topik yang paling banyak adalah coronavirus infections, pneumonia, viral, corona virus infection. Sedang topik yang lainnya adalah stress, quarantine, mental stress, stress psychological, virology.

4. Kelompok warna kuning terdapat 3 topik yaitu art, patient care, health care personnel.

\section{B. Kata Kunci Psikologi Seni}

Dari hasil penelusuran di basis data scopus dengan kata kunci art psychology diperoleh sebanyak 1952 artikel. Hasil pengelompokan kata kunci dari analisis menggunakan perangkat lunak VOSviewer sebagai berikut :

1. Kelompok warna merah terdapat 7 topik. Topik yang paling banyak behavioral research, learning systems, face recognition dan semantics. Topik yang lain adalah facial expressions, color, 


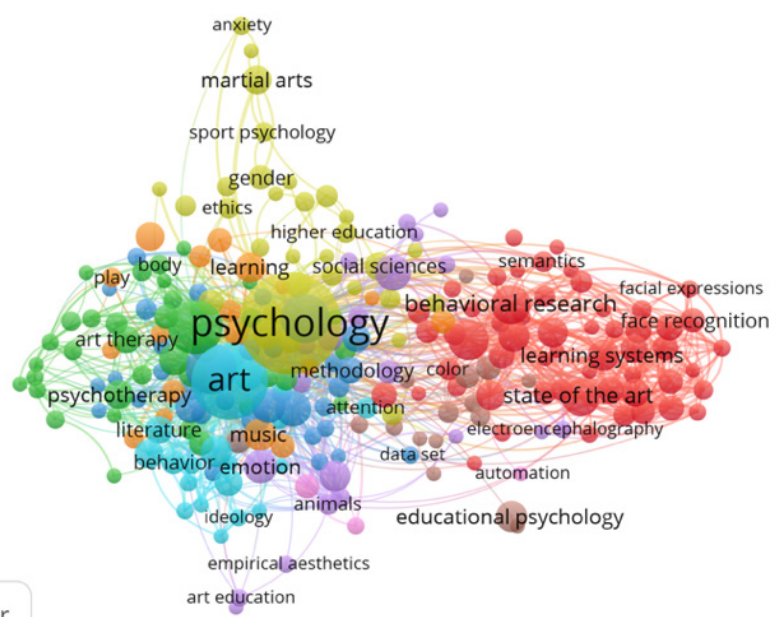

Gambar 2. Analisis Bibliometrik Psikologi Seni (Sumber : Hasil Penelitian, 2021)

electroencephalography.

2. Kelompok warna hijau terdapat 3 topik yaitu art therapy, psychotherapy, body.

3. Kelompok warna biru terdapat 6 topik. Topik yang paling banyak adalah art. Sedang topik lain adalah literature, behavor, ideology, methodology, attention.

4. Kelompok warna kuning terdapat 7 topik. Topik yang paling banyak adalah psychology. Topik yang lain adalah anxiety, martial arts, gender, ethics, higher education.

5. Kelompok warna orange terdapat 3 topik yaitu music, learning, play.

6. Kelompok warna ungu terdapat 5 topik. Topik yang paling banyak adalah sosial sciences, animals, emotion. Topik yang lainnya adalah empirical aesthetics, art education.

7. Kelompok warna coklat terdapat 2 topik yaitu educational psychology, automation.

Kemudian dari hasil analisis subyek artikel pada literatur psikologi seni divisualisasikan dengan word-cloud. Word cloud (Tuan, 2016, hlm. 2) merupakan bentuk visualisasi teks sebagai hasil analisis nilai

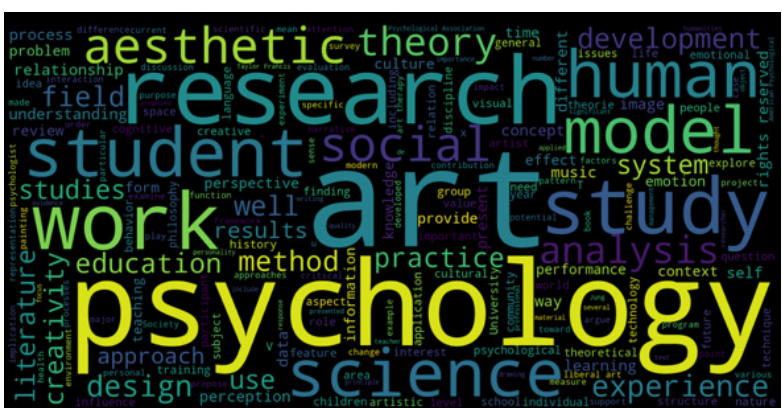

Gambar 3. Analisis Word-Cloud Psikologi Seni (Sumber : Hasil Penelitian, 2021)

Grafik 2. Kata Kunci Literasi Bidang Psikologi Seni (Sumber : Hasil Penelitian, 2021)

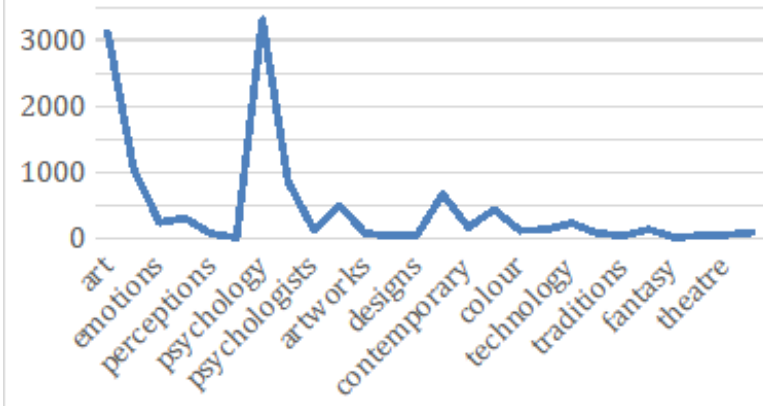

sosial dan estetika. Visualisasi ini membantu untuk melihat persamaan dan perbedaan antar dokumen melalui word cloud. Word cloud sebagai bentuk visualiasi yang paling popular. Atribut visual (Tuan, 2016, hlm. 4) yaitu ukuran huruf, warna dan posisi.

Penelusuran dengan kata kunci psikologi (psychology) menghasilkan sejumlah artikel 3307 artikel, sedangkan kata kunci seni (art) sebanyak 3111 artikel. Kata kunci lain yang berkaitan dengan psikologi dan seni adalah emosi, persepsi, negativitas, psikolog, kreativitas, kerja seni, piktorial, desain, kontemporer, budaya, warna, digital, teknologi, tradisi, tari, fantasi, well-being, teater dan pariwisata. Kata kunci literasi bidang psikologi seni dapat dilihat pada grafik 2 .

Hasil penelitian Jenine Milum (2018, hlm. 6-7) menjelaskan arti warna dalam analisis sentimen yaitu hijau berarti positif, kuning berarti netral dan merah berarti 


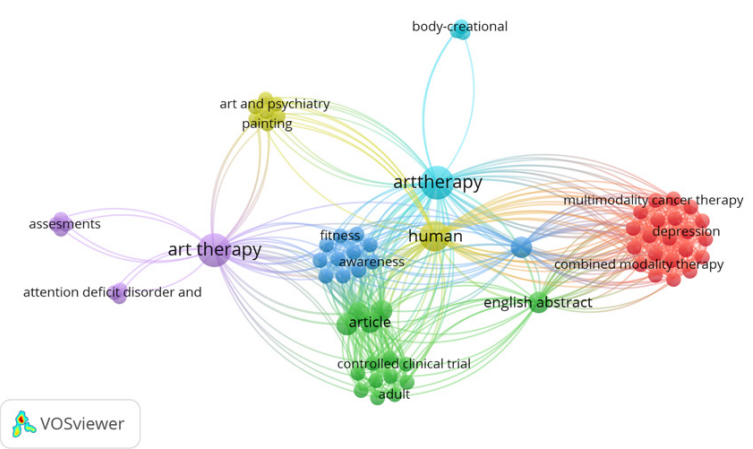

Gambar 4. Analisis Bibliometrik Terapi Seni (Sumber : Hasil Penelitian, 2021)

negatif. Pemaknaan warna ini berbeda artinya dengan warna yang dihasilkan pada analisis word-cloud dan analisis co-word.

\section{Kata Kunci Terapi Seni}

Dari hasil penelusuran di basis data scopus dengan kata kunci art therapy diperoleh sebanyak 13 artikel. Hasil pengelompokan kata kunci dari analisis menggunakan perangkat lunak VOSviewer sebagai berikut:

1. Kelompok warna merah 3 topik yaitu depression, multimodality cancer therapy, combined modality therapy.

2. Kelompok warna hijau 2 topik yaitu controlled clinical trial dan adult.

3. Kelompok warna biru 4 topik yaitu art therapy, fitness, body creational dan awareness.

4. Kelompok warna kuning 3 topik yaitu human, art and psychiatry, painting.

5. Kelompok warna ungu 3 topik yaitu art therapy, assesments, attention deficit disorder

\section{Kata Kunci Psikoterapi dan Seni}

Dari hasil penelusuran di basis data scopus dengan kata kunci psychotherapy dan art diperoleh sebanyak 811 artikel. Hasil

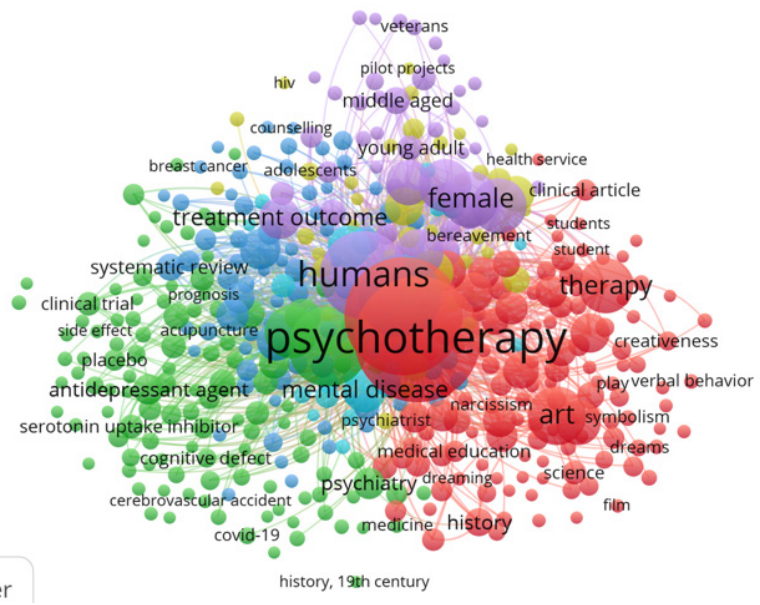

Gambar 5. Analisis Bibliometrik Psikoterapi dan Seni (Sumber : Hasil Penelitian, 2021)

pengelompokan kata kunci dari analisis menggunakan perangkat lunak VOSviewer sebagai berikut:

1. Kelompok warna merah terdapat $\mathbf{1 4}$ topik. Topik yang paling banyak adalah psychotherapy, therapy, dan art. Topik yang lain adalah creativeness, play, verbal behavior, symbolism, dreams, science, film, history, dreaming, medical education narcissism, health service.

2. Kelompok warna hijau terdapat 14 topik yaitu psychiatry, cognitive defect, medicine, cerebrovascular accident, covid-19, cognitive defect, serotonin, uptake inhibitor, antidepressant agent, placebo, acupuncture, side effect, clinical trial, prognosis,

3. Kelompok warna biru terdapat 4 topik yaitu mental disease, psychiatrist, breast cancer, counselling.

4. Kelompok warna ungu terdapat 7 topik yaitu female, treatment outcome, adolescents, young adult, middle aged, pilot projects, veterans. 
Tabel 2. Klasifikasi Area Topik

(Sumber : Hasil Penelitian, 2021)

\begin{tabular}{|c|c|c|c|}
\hline No. & Bidang & Topik & Subtopik \\
\hline \multirow[t]{4}{*}{1.} & Seni dan Terapi & $\begin{array}{l}\text { Kesehatan } \\
\text { Mental } \\
\text { (Psikologi } \\
\text { Klinis) }\end{array}$ & $\begin{array}{l}\text { Gangguan mental, Gangguan paranoid, } \\
\text { Skiizofrenia, Fobia, depresi, kecemasan, } \\
\text { stres, stres mental, stres psikologis }\end{array}$ \\
\hline & & $\begin{array}{l}\text { Psikoterapi } \\
\text { (psikiatri) }\end{array}$ & Epilepsi, memori, patofisiologi \\
\hline & & $\begin{array}{l}\text { Medium Terapi } \\
\text { Seni }\end{array}$ & $\begin{array}{l}\text { Lukisan, patung, musik, film, bela diri } \\
\text { (simbolisme, perawatan pasien) }\end{array}$ \\
\hline & & Terapi Keluarga & $\begin{array}{l}\text { Kreativitas, bermain, petugas kesehatan } \\
\text { (Parkinson, vertigo, Alzheimer) }\end{array}$ \\
\hline 2. & $\begin{array}{l}\text { Seni dan Halusinasi } \\
\text { (Psikiatri) }\end{array}$ & Estetika Nalar & Estetika, pendidikan seni, halusinasi \\
\hline 3. & $\begin{array}{l}\text { Seni, Psikologi dan } \\
\text { Teknologi }\end{array}$ & $\begin{array}{l}\text { Psikologi } \\
\text { Artifisial }\end{array}$ & $\begin{array}{l}\text { Rekognisi wajah, ekspresi wajah, warna, } \\
\text { elektroensefalografi }\end{array}$ \\
\hline
\end{tabular}

Tabel 2. Klasifikasi Area Topik

(Sumber : Hasil Penelitian, 2021)

\begin{tabular}{|c|c|c|}
\hline $\begin{array}{l}\text { Tipe } 1 \text { Masalah } \\
\text { Psikologis Umum }\end{array}$ & Tipe 2 Masalah Psikologi Klinis (CPPs) & $\begin{array}{l}\text { Tipe } 3 \text { Masalah } \\
\text { Psikopatologis } \\
\text { (Gangguan Mental) }\end{array}$ \\
\hline $\begin{array}{l}\text { Reaksi psikologis } \\
\text { "linier" normal. } \\
\text { Tidak ada PMC } \\
\text { yang teridentifikasi. }\end{array}$ & $\begin{array}{l}\text { Reaksi psikologis yang tidak diinginkan } \\
\text { terus menerus. } \\
\text { PMC telah terbentuk. }\end{array}$ & $\begin{array}{l}\text { Kondisi psikopatologis } \\
\text { yang didiagnosa. } \\
\text { PMC psikologis dan PMC } \\
\text { biologis terjadi. }\end{array}$ \\
\hline $\begin{array}{l}\text { Rujukan untuk } \\
\text { konseling }\end{array}$ & Rujukan untuk terapi psikologis klinis & $\begin{array}{l}\text { Rujukan untuk terapi } \\
\text { psikiatri dan psikologis }\end{array}$ \\
\hline $\begin{array}{l}\text { 1. Gangguan stres } \\
\text { akut } \\
\text { 2. Kondisi kecema- } \\
\text { san } \\
\text { 3. Stres peristiwa } \\
\text { kehidupan } \\
\text { 4. Transisi hidup } \\
\text { 5. Gangguan penye- } \\
\text { suaian } \\
\text { 6. Masalah kepriba- } \\
\text { dian/personalitas } \\
\text { 7. Kelelahan }\end{array}$ & $\begin{array}{l}\text { 1. Gangguan kecemasan (panik, fobia } \\
\text { spesifik dsb) } \\
\text { 2. Depresi } \\
\text { 3. Gangguan makan } \\
\text { 4. Obsesif-kompulsif atau gangguan } \\
\text { lainnya } \\
\text { 5. Masalah seksual } \\
\text { 6. Gangguan stress pascatrauma } \\
\text { 7. Masalah hubungan/relasi } \\
\text { 8. Penyalahgunaan obat } \\
\text { 9. Gangguan perjudian } \\
\text { 10. Masalah tidur } \\
\text { 11. Gangguan kepribadian/personalitas } \\
\text { 12. Gangguan kesedihan berkepanjangan }\end{array}$ & \\
\hline
\end{tabular}




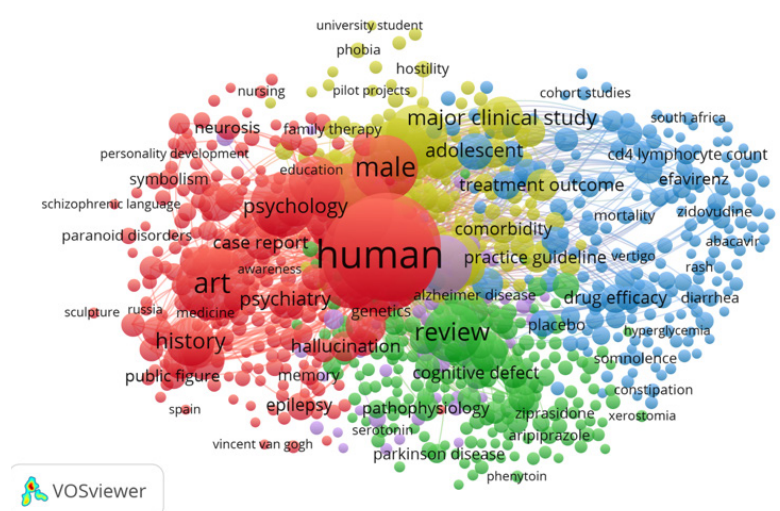

Gambar 6. Analisis Bibliometrik Psikosis dan Seni (Sumber : Hasil Penelitian, 2021)

\section{E. Kata Kunci Psikosis dan Seni}

Dari hasil penelusuran di basis data scopus dengan kata kunci psychosis dan art diperoleh sebanyak 825 artikel. Hasil pengelompokan kata kunci dari analisis menggunakan perangkat lunak VOSviewer sebagai berikut :

1. Kelompok warna merah terdapat $\mathbf{2 6}$ topik. Topik yang paling banyak adalah human, art, psychology, male, history. Topik yang lain adalah education, psychiatry, hallucination, epilepsy, memory, genetics, awareness, spain, Vincent van gogh, public figure, medicine, Russia, sculpture, paranoid disorders, schizophrenic language, symbolism, personality development, neurosis, education, family therapy, nursing.

2. Kelompok warna hijau terdapat 6 topik yaitu cognitive defect, pathophysiology, Parkinson disease, ziprasidone, aripipraxole, phenytoin.

3. Kelompok warna biru terdapat $\mathbf{1 7}$ topik yaitu drug efficacy, treatment outcome, placebo, adolescent, cohort studies, sout Africa, cd4 lymphocyte count, efavirenz, zidovudine, abacavi, diarrhea, hyperglycemia, somnolence, constipation, xerostomia, vertigo, mortality.
4. Kelompok warna kuning terdapat 4 topik yaitu major clinical study, comorbidity, hostility, phobia.

5. Kelompok warna ungu terdapat 1 topik yaitu alcheimer disease.

Dari hasil analisis co-word dan analisis word-cloud kemudian dapat diklasifikasi area topik untuk dipetakan kedalam ranah Taksonomi Psikologi Seni seperti yang dapat dilihat pada tabel 2.

Hasil klasifikasi area topik ini dikaitkan dengan hasil penelitian Gary M. Bakker (2019, hlm. 19) tentang berbagai jenis masalah psikologis yang dibagi menjadi 3 tipe yaitu masalah psikologis umum, masalah psikologi klinis dan masalah psikopatologis (gangguan mental) seperti yang dijelaskan pada tabel 3.

Dari ketiga tipe masalah psikologi tersebut dapat dilakukan intervensi seni sesuai klasifikasi area topik misal stress pada tipe 1, depresi pada tipe 2 atau skizofrenia pada tipe 3 .

\section{SIMPULAN}

Dari hasil penelitian bibliometrik dapat disimpulkan bahwa taksonomi intervensi seni kreatif untuk kesehatan mental dapat diklasifikasikan ke dalam area topik yang sering muncul dalam ranah ilmu psikologi seni. Klasifikasi area topik dikelompokan berdasarkan bidang, topik dan subtopik. Dari subtopik yang dianalisis dapat diketahui jenis masalah psikologisnya berdasarkan tipe 1, tipe 2 dan tipe 3.

Hierarki taksonomi PTSD berdasarkan gejalanya dibagi menjadi perilaku, kognitif, emosi, fungsional dan fisik. Ranah penelitian 
psikologi seni yaitu kreativitas, estetika dan proses kreatif. Kemudian hierarki taksonomi pada bidang ilmu psikologi seni dibagi menjadi intervensi seni dan assessment/ screening. Dari tipe masalah psikologi dapat dilakukan intervensi seni sesuai klasifikasi area topik.

\section{UCAPAN TERIMA KASIH}

Penulis mengucapkan terima kasih kepada Pusat Penelitian Seni (ARC) Universitas Ritsumeikan Kyoto Jepang, Institut Seni Budaya Indonesia Bandung dan Universitas 17 Agustus 1945 Surabaya yang telah memberi dukungan serta memfasilitasi pelaksanaan penelitian ini.

\section{DAFTAR PUSTAKA}

Anderson, Lorin W. (2001). A Taxonomy for Learning, Teaching and Assessing: A Revision of Bloom's Taxonomy of Edcuational Objective. New York: Addison Wesley Longman Inc

Bakker, Gary M. (2019). "A new conception and subsequent taxonomy of clinical psychological problems". BMC Psyhology: 7 (46), DOI : 10.1186/s40359019-01318-8

Carney, James. (2019). "Culture and mood disorders : The Effect of abstraction in image, narrative and film on depression and anxiety". Med Humanities: 46 (4), 1-14, DOI : 10.1136/ medhum-2018-011459

Chandrashekara, M., K.R. Mulla, N.S. Harinarayana dan Ramachandra. (2010). "Bibliometric Analysis of Literature Published in Emerald
Publications on Digital Libraries". Library Science: 1 (110)

Christiani, Yuri, Mulyanto, Adam Wahida. (2021). “Terapi Seni di Masa Pandemi Corona Virus Disease-19 (Covid-19)". Panggung: 31 (1), 106-116, DOI : http://dx.doi.org/10.26742/panggung. v31i1.1537

Delecroix, B., R. Eppstein. (2004). "CoWord Analysis for the non-scientific information example of reuters Business Briefings". Data Science Journal: 3 (15)

Fernandez-Cao, Marian Lopez, Celia CamiliTrujillo, Laura Fernandez-Escudero. (2020). "Projecta : An Art-Based Tool in Trauma Treatment". Methods : Frontiers in Psychology: 1 (568948)1, 1-18, DOI : 10.3389/fpsyg.2020.568948

Hall, Johanna, Ursula Stickler, Christothea Herodotou, Ioanna Lacovides. (2019), "Player conceptualizations of Creativity in Digital Entertainment Games", Convergence: The International Journal of Research into New Media Technologies: 26 (5-6), 1-22, DOI : 10.1177/1354856519880791

Jenkins, L.K., R. Farrer, I.J. Aujla. (2021). "Understanding the impact of an intergenerational arts and health project : a study into the psychological well-being of participants, carers and artists". Public Health : 194, 121-126, DOI : 10.1016/j.puhe.2021.02.029

Kagan, Vadim, Edward Rossini, Demetrios Sapounas. (2013). Sentiment Analysis for PTSD Signals. New York : Springer

Khalili, Abdullah, Hamid Bouchachia. (2021). "An information Theory Approach to Aesthetic Assessment of Visual Patterns". Entropy: 23 (153), DOI : 10.3390/e23020153

Larrain, Antonia, Andres Haye. (2020). “The dialogical and political nature of emotions : A reading of Vygotsky's The Psychology of Art". Theory and Psychology: 30 (6), 800-812, DOI : 10.1177/0959354320955235

Milum, Jenine. (2018). Visual Analytics : Text Analytics Using Word Clouds. Atlanta : SAS 
McNaught, Carmel, Paul Lam. (2016). “Using Wordle as a Supplementary Research Tool". The Qualitative Report : 15 (3)

McCormack, Jon, Andy Lomas. 2020. “Deep Learning of Individual Aesthetics", Neural Computing and Applications, DOI :10.1007/s00521-020-05376-7

Piliang, Yasraf A. (2014). "Kreativitas Desain Kuliner dan Sistem Inovasi Lokal". Panggung: 24 (3), 285-294, DOI : http://dx.doi.org/10.26742/panggung. v24i3.125

Sau, Arkaprabha, Ishita Bhakta (2018). "Screening of anxiety and depression among the seafarers using machine learning technology". Informatics in Medicine Unlocked, 1-7, DOI : 10.1016/j. imu.2018.12.004

Silvia P.J., et.al. (2021). "Aethetic Preference for Glossy Materials : An Attempted Replication and Extension". Behavioral Sciences: 11 (4)

Sirgy, M. Joseph (2012). The Psychology of Quality of Life : Hedonic Well-Being, Life Satisfaction, and Eudaimonia. London : Springer

Schoch K, Ostermann T. (2021). “Giving the Art Greater Weight in Art Psychology : RizbA, a Questionnaire for Formal Picture Analysis". Creativity: 7 (2)

Shevlin, Henry. (2021). "Rethinking creative intelligence : comparative psychology and the concept of creativity". European Journal for Philosophy of Science: 11 (16), 1-21, DOI : $10.1007 / \mathrm{s} 13194-020-00323-8$

Tomlinson, Alan, et.al. (2018). Visual Art and Mental Health. London : University of Brighton

Tuan M. V. , LAUW, Hady W. (2016). "Word clouds with latent variable analysis for visual comparison of documents". Proceedings of the 25th International Joint Conference on Artificial Intelligence IJCAI 2016: New York, July 9-15. 2536-2543. Research Collection School Of Information Systems, https://ink.library.smu.edu.sg/sis_ research/3357

Weizz, Selina, Oliver Wilhelm. (2020). “Coda: Creativity in Psychological Research versus in Linguistic - Same but different?". Coginitive Semiotics, 1-15, DOI : 10.1515/cogsem-2020-2029

Yue, Hongjiang. (2011). "Visualization the Subject Structure of International Management Science by Co-Word Analysis". 2011 International Conference on Intormation Management, Innovation Management and Industrial Engineering, 129-132, DOI : 10.1109/ICIII.2011.314

Zhao, Fangkun, et.al. (2018). "Theme trends and knowledge structure on choroidal neovascularization : A Quantitative and Co-Word Analysis", BMC Ophthalmology: 18 (86). 1-11, DOI : 10.1186/s12886-018-0752-z 